\title{
Kepatuhan Minum ARV pada Anak dengan HIV
}

\author{
Adherence to Taking ARVs in Children with HIV
}

\author{
Nuraidah*, Farida Murtiani \\ RSPI Prof. Dr. Sulianti Saroso, Kementerian Kesehatan Republik Indonesia
}

Korespondensi Penulis :

Nuraidah

Email : nuraidah.ai@gmail.com

\begin{abstract}
Abstrak
Latar Belakang: Anak dengan HIV menjalani terapi ARV jangka panjang yang berpengaruh terhadap pengobatan dan status kesehatannya. Penelitian ini bertujuan untuk mengetahui hubungan antara efek samping dengan kepatuhan minum obat Antiretroviral (ARV) dan menganalisis kepatuhan minum obat dengan status tumbuh kembang anak dan penyakit penyerta. Metode: Desain penelitian crossectional. Sampel dalam penelitian ini adalah anak dengan HIV yang menjalani terapi ARV di RSPI Prof. Dr. Sulianti Saroso Jakarta. Pengambilan sampel dengan total sampling dengan total 56 anak. Hasil: Analisis efek samping dengan kepatuhan diperoleh nilai $P$-value $1,000>0,05$. Analisis Kepatuhan dengan status tumbuh kembang diperoleh nilai $P$-value $1,000>0,05$. Analisis kepatuhan minum ARV dengan penyakit penyerta diperoleh nilai $\mathrm{P}$-value $0,004<0,05$. Kesimpulan: kepatuhan minum ARV berhubungan dengan penyakit penyerta selama pengobatan.
\end{abstract}

Kata kunci : kepatuhan, ARV, anak

\begin{abstract}
Background: Children with HIV undergo long-term ARV therapy which affects their medication and health status. This study aims to determine the relationship between ARV therapy side effects and adherence to taking antiretroviral (ARV) drugs, and to analyze the relationship between adherence to taking medication and child development status and comorbidities. Method: This research employed a cross-sectional design. The research sample were children with HIV who were undergoing ARV therapy at RSPI Prof. Dr. Sulianti Saroso in Jakarta. The sample consisted of a total of 56 children. Results: The $p$ value obtained from the analysis of the relationship between ARV side effects and adherence to taking antiretroviral (ARV) drugs was 1.000>0.05. The $p$ value obtained from the analysis of the relationship between adherence to taking antiretroviral (ARV) drugs and child development status was 1.000>0.05. Meanwhile, the analysis of the relationship between adherence to taking $A R V$ and comorbidities revealed a $p$ value of $0.004<0.05$. Conclusion: Adherence to taking ARVs is related to comorbidities during treatment.

Keywords: adherence, $A R V$, children
\end{abstract}




\section{Pendahuluan}

Human Immunodeficiency virus (HIV) adala penyakit infeksi yang menular melalui darah cairan tubuh dan kontak langsung melalui cairan mukosa dengan penderita HIV/AIDS. Berdasarkan data Joint United Nations Programme on HIV and AIDS (UNAIDS) tahun 2018 jumlah penduduk dunia yang terkena HIV pada tahun 2018 berjumlah 37,9 juta jiwa. 1,7 juta diantaranya adalah yang mengalami infeksi baru. Data yang diterbitkan Kemenkes (2019) menunjukkan jumlah kumulatif HIV sampai Juni 2019 adalah 349.882 dan yang mengalami AIDS sebanyak 117.064 orang. DKI Jakarta menjadi provinsi yang memiliki jumlah kumulatif kasus HIV terbanyak yaitu 62.108 orang $(17,75 \%)$ dari jumlah total nasional, dan yang mengalami AIDS sebanyak 10.242 orang $(8,74 \%) .{ }^{(1)}$

Kepatuhan pengobatan ARV merupakan tantangan tersendiri karena pengobatan ARV harus dijalani seumur hidup oleh anak. Tantangan lain yang harus dihadapi selain virus HIV itu sendiri yakni infeksi oportunistik dan kondisi terkait HIV lainnya, efek samping dari terapi antiretroviral (ART) dan tantangan lain dalam konteks sosial(2).

Pada kasus HIV anak perjalanan penyakit HIV banyak terjadi sejak anak masih dalam kandungan atau masa perinatal dan sebagian besar anak tidak mengetahui status HIV yang dialaminya ${ }^{(3)}$. Ketika anak sudah mulai remaja rasa bosan dalam minum ARV mulai muncul hal ini dikarenakan ketidak tahuan apa manfaat obat yang diminum sehingga terkadang anak melewatkan dosis ARV.

Salah satu upaya pemerintah dalam meningkatkan kepatuhan minum obat adalah menyediakan regimen pengobatan ARV kombinasi dosis tetap (KDT-Fixed Dose Combination-FDC) yang berarti dalam satu tablet mengandung tiga obat, sehingga pasien minum satu tablet obat dalam jam yang sama untuk mempertahankan kepatuhan pasien dalam pengobatan $A R V^{(4)}$. Kepatuhan minum obat klien HIV/AIDS meliputi ketepatan dalam waktu, jumlah, dosis, serta cara individu dalam mengkonsumsi obat. Ketidakpatuhan dalam pelaksanaan terapi akan meningkatkan resistensi virus dalam tubuh. Seorang pasien dengan HIV akan dikatakan patuh pengobatan apabila ARV yang diminum mencapai $95 \%$ dari total obat yang diberikan setiap bulannya dan dapat mempertahankan ketepatan waktu minum $A R V^{(5)}$. Banyak hal yang menyebabkan pasien anak dengan HIV tidak patuh dalam pengobatan sehingga hal ini harus kita identifikasi. Berdasarkan hal tersebut tujuan 
penelitian ini adalah untuk mengetahui hubungan kepatuhan minum ARV dengan status tumbuh kembang dan penyakit penyerta yang dialami anak serta analisa efek samping dengan kepatuhan minum obat.

\section{Metode}

Penelitian dilakukan di RSPI Prof $\mathrm{Dr}$ Sulianti Saroso karena RSPI merupakan rumah sakit rujukan nasional infeksi yang memberikan pelayanan perawatan dan pengobatan pada pasien HIV/AIDS. Desain penelitian yang digunakan adalah penelitian deskriptif dengan pendekatan crosectional. Populasi penelitian ini adalah seluruh pasien anak yang menjalani terapi ARV. Sampel penelitian adalah semua anak dengan HIV yang menjalani terapi ARV di RSPI Prof Dr Sulianti Saroso dengan kriteria inklusi Anak dengan HIV usia 1 bulan sampai dengan 18 tahun dan mendapat terapi ARV. Jumlah populasi dalam penelitian ini sebanyak 59 orang, dan sampel yang sesuai dengan kriteria inklusi adalah sebanyak 56 orang dikarenakan 3 orang karena data tidak lengkap. Data dikumpulkan melalui penelusuran data rekam medis pasien anak dengan HIV yang menjalani terapi ARV di RSPI Prof Dr Sulianti Saroso Jakarta dari Januari 2014 sampai
Desember 2018. Variabel penelitian ini adalah status tumbuh kembang yakni berdasarkan pengukuran berat badan dan tinggi badan serta kesesuaian kemampuan anak dengan usianya, penyakit penyerta dan efek samping obat. Analisis yang dilakukan adalah Univariat dan Bivariat. Penelitian ini telah mendapat ethical clearance dari komite etik RSPI Prof Dr Sulianti Saroso dengan nomor izin etik 38/XXXVIII.10/VIII/2019

\section{Hasil}

Pasien anak dengan HIV di RS. Prof. Dr. Sulianti Saroso berdasarkan karakteristik demografi sebagian besar berusia prasekolah (> 3-5 Tahun) sebanyak 27 (48,21\%), berjenis kelamin laki-laki sebanyak 30 (53,57\%) dan sumber penularan transmisi vertikal sebanyak $54(96,43 \%)$ (Tabel 1).

Tabel 1. Karakteristik Responden $(n=56)$

\begin{tabular}{lcc}
\hline \multicolumn{1}{c}{ Karakteristik } & $\mathbf{n}$ & $\%$ \\
\hline Umur & & \\
- Infant (1bulan-1 tahun) & 5 & 8.93 \\
- Toddler (>1-3 tahun) & 16 & 28.57 \\
- Prasekolah (>3-5 tahun) & 27 & 48.21 \\
- Usia Sekolah(>6-12 & 5 & 8.93 \\
$\quad$ tahun) & 3 & 5.36 \\
- Remaja(>13-18 tahun) & & \\
Jenis Kelamin & 30 & 53.57 \\
- Laki - laki & 26 & 46.43 \\
- Perempuan & & \\
\hline Sumber Penularan & 54 & 96.43 \\
- Transmisi Vertikal & 2 & 3.57 \\
- Transmisi Horizontal & \multicolumn{2}{c}{}
\end{tabular}


Pasien anak dengan HIV di RS. Prof. Dr. Sulianti Saroso yang menjalani terapi ARV sebagian besar patuh pengobatan yaitu 49 (87,5\%), menyatakan tidak ada efek samping yaitu $50(89,3 \%)$ dan dengan penyakit penyerta TB paru yaitu 29 (51,8\%) (Tabel 2).

Efek samping tersebut berdampak pada kepatuhan pasien dalam minum obat. Hasil penelitian menunjukkan bahwa dari 6 pasien yang mengalami efek samping seluruhnya patuh dan dari 50 pasien yang tidak mengalami efek samping sebagian besar 43 (86\%) patuh pengobatan. Hasil analisis dengan uji chi square diperoleh Pvalue
$=1,000 \quad(<0.05)$ yang berarti efek samping pengobatan tidak berhubungan secara signifikan dengan kepatuhan minum ARV ( Tabel 3).

Tabel 2. Distribusi Frekuensi Kepatuhan, Efek Samping dan Penyakit Penyerta $(n=56)$

\begin{tabular}{lcc}
\hline \multicolumn{1}{c}{ Variabel } & n & Persen (\%) \\
\hline $\begin{array}{l}\text { Kepatuhan } \\
\text { Pengobatan }\end{array}$ & & \\
- Tidak Patuh & 7 & 12,5 \\
- Patuh & 49 & 87,5 \\
\hline Efek Samping & & \\
- Ada & 6 & 10,7 \\
- Tidak ada & 50 & 89,3 \\
\hline Penyakit & & \\
Penyerta & & \\
- TB Paru & 29 & 51,8 \\
- Candidiasis & 5 & 8,9 \\
- Penumonia & 6 & 10,7 \\
- Tidak Ada & 4 & 7,1 \\
- Lain-lain & 12 & 21,4 \\
\hline
\end{tabular}

Tabel 3. Analisis Efek samping obat dengan Kepatuhan Minum ARV

\begin{tabular}{|c|c|c|c|c|c|c|c|}
\hline \multirow[t]{3}{*}{ Efek samping } & \multicolumn{4}{|c|}{ Kepatuhan } & \multirow{2}{*}{\multicolumn{2}{|c|}{ Total }} & \multirow[t]{3}{*}{ P Value } \\
\hline & \multicolumn{2}{|c|}{ Tidak patuh } & \multicolumn{2}{|c|}{ Patuh } & & & \\
\hline & $\mathbf{n}$ & $\%$ & $\mathbf{n}$ & $\%$ & $\mathbf{n}$ & $\%$ & \\
\hline Ada & 0 & 0 & 6 & 100 & 6 & 100 & $1,000^{*}$ \\
\hline Tidak ada & 7 & 14 & 43 & 86 & 50 & 100 & \\
\hline Jumlah & 7 & 12,5 & 49 & 87,5 & 56 & 100 & \\
\hline
\end{tabular}

*Uji chi square

Analisis kepatuhan minum ARV dengan status tumbuh kembang diketahui bahwa dari 7 pasien yang tidak patuh seluruhnya tidak mengalami gangguan tumbuh kembang sedangkan daru 49 pasien yang patuh sebagian besar yaitu 46 (93,9\%) tidak mengalami gangguan tumbuh kembang. Hasil analisis dengan uji chi square diperoleh Pvalue $=1,000 \quad(<0.05)$ yang berarti kepatuhan tidak berhubungan secara signifikan dengan status tumbuh kembang ( Tabel 4).

Hasil analisis kepatuhan dengan penyakit penyerta diketahui bahwa dari 7 pasien yang tidak patuh sebagian besar mengalami candidiasi yaitu 3 $(42,9 \%)$ sedangkan dari 49 pasien yang patuh sebagian besar yaitu 29 (51,2\%) mengalami Tb paru (Tabel 5). 
Tabel 4. Analisis Hubungan Kepatuhan Minum ARV dengan Status Tumbuh Kembang

\begin{tabular}{|c|c|c|c|c|c|c|c|}
\hline \multirow{3}{*}{ Kepatuhan } & \multicolumn{4}{|c|}{ Status tumbuh kembang } & & & \multirow[t]{3}{*}{ P Value } \\
\hline & \multicolumn{2}{|c|}{ Ada gangguan } & \multicolumn{2}{|c|}{ Tidak ada gangguan } & \multicolumn{2}{|c|}{ Total } & \\
\hline & $\mathbf{n}$ & $\%$ & $\mathbf{n}$ & $\%$ & $\mathbf{n}$ & $\%$ & \\
\hline Tidak Patuh & 0 & 0 & 7 & 100 & 7 & 100 & 1,000 \\
\hline Patuh & 3 & 6.1 & 46 & 93.9 & 49 & 100 & \\
\hline Jumlah & 3 & 5.4 & 53 & 94.6 & 56 & 100 & \\
\hline
\end{tabular}

${ }^{*}$ Uji chi square

Tabel 5. Analisis Hubungan Kepatuhan Minum ARV dengan Penyakit Penyerta

\begin{tabular}{|c|c|c|c|c|c|c|c|c|c|c|c|c|c|}
\hline \multirow{3}{*}{ Kepatuhan } & \multicolumn{10}{|c|}{ Penyakit penyerta } & \multirow{2}{*}{\multicolumn{2}{|c|}{ Total }} & \multirow{3}{*}{$\begin{array}{c}P \\
\text { Value }\end{array}$} \\
\hline & \multicolumn{2}{|c|}{ TB Paru } & \multicolumn{2}{|c|}{ Candidiasis } & \multicolumn{2}{|c|}{ Pneumonia } & \multicolumn{2}{|c|}{$\begin{array}{c}\text { Tidak } \\
\text { ada }\end{array}$} & \multicolumn{2}{|c|}{ Lain-lain } & & & \\
\hline & $\mathbf{n}$ & $\%$ & $\mathbf{n}$ & $\%$ & $\mathrm{n}$ & $\%$ & $n$ & $\%$ & $n$ & $\%$ & $\mathrm{n}$ & $\%$ & \\
\hline Tidak patuh & 0 & 0 & 3 & 42,9 & 1 & 14,3 & 1 & 14,3 & 2 & 28,6 & 7 & 100 & * \\
\hline Patuh & 29 & 51,2 & 2 & 4,1 & 5 & 10,2 & 3 & 6,1 & 10 & 20,4 & 49 & 100 & $0,02^{\prime \prime}$ \\
\hline Jumlah & 29 & 59,81 & 5 & 8,9 & 6 & 10,7 & 4 & 7,1 & 12 & 21,4 & 56 & 100 & \\
\hline
\end{tabular}

*Uji Kendall's Tau

\section{Pembahasan}

Hasil penelitian didapat dari 56 sampel anak dengan HIV / AIDS yang menjalani terapi ARV, paling banyak adalah usia pra sekolah (umur 4-6 tahun) sebanyak 27 orang atau $48,21 \%$ dengan jenis kelamin proporsi laki laki lebih banyak yakni berjumlah 30 orang atau $53,57 \%$. Hal ini didukung oleh penelitian tahun 2017 bahwa anak HIV lebih banyak pada usia $\leq 5$ tahun. ${ }^{(6)}$ Saat ini kejadian HIV/AIDS dilaporkan lebih banyak pada laki-laki hampir pada setiap Negara. ${ }^{(7)}$ Sebagian besar (96.43\%) sumber penularan HIV/AIDS pada anak usia 1 bulan sampai 18 tahun diakibatkan karena transmisi vertikal, riwayat proses persalinan yang paling banyak adalah proses persalinan secara spontan yakni berjumlah 29 orang atau $51,79 \%$. Berdasarkan data
Ditjen PP \& PL Kemenkes RI tahun 2014 tentang kasus HIV/AIDS di Indonesia bahwa anak HIV paling banyak pada usia kurang dari 5 tahun terjadi karena penularan dari ibu ke anak pada masa kehamilan (intrauterine) selama persalinan (intrapartum) atau setelah melahirkan (melalui menyusui). Hal ini senada dengan penelitian yang dilakukan oleh Lovero et al (2018) menyatakan bahwa tanpa pengobatan profilaksis, penularan dari ibu ke anak terjadi pada sekitar $20-45 \%$ bayi lahir dari wanita yang terinfeksi HIV. ${ }^{(8)}$ Upaya yang dilakukan untuk mencegah penularan HIV melalui ibu adalah Prevention of Mother To Child Transmission (PMTCT). ${ }^{(1)}$

Ketidakpatuhan anak dalam pengobatan ARV dapat disebabkan 
oleh karena sediaan obat yang terbatas untuk anak sehingga mempersulit ketepatan dosis yang diberikan, efek samping, bosan dan jenuh minum obat, stigma dan diskriminasi, hubungan yang tidak baik antara tenaga kesehatan dengan keluarga serta adanya penyakit lain yang menyebabkan anak meminum obat selain ARV serta perubahan pengasuh. ${ }^{(9)}$ Kepatuhan adalah faktor penting dalam keberhasilan terapi ARV. Dalam penelitian ini menunjukan bahwa sebagian besar anak dengan HIV patuh pengobatan. Kepatuhan tersebut terbentuk merupakan kesadaran pasien dan kerjasama yang baik antara tenaga kesehatan dan keluarga.

Sebagian besar pasien anak menyatakan tidak ada efek samping yaitu 50 (89,3\%). Hal ini membuktikan bahwa obat ARV apabila diberikan dengan benar dan dosis yang tepat memiliki keamanan yang tinggi. Terapi ARV direkomendasikan untuk semua pasien dengan HIV.(10) Obat ini disediakan secara gratis melalui program pemerintah Indonesia.

Anak dengan HIV sebagian besar dengan penyakit penyerta TB paru yaitu 29 (51,8\%). Epidemi HIV memberikan kontribusi pengaruh terhadap peningkatan kasus TB. Sebagian besar orang yang terinfeksi kuman

TB

(Mycobacterium tuberculosis) tidak menjadi sakit TB jika mempunyai sistem imunitas yang baik yang dikenal sebagai infeksi TB laten. Namun orang yang sistem imunitasnya menurun seperti pada orang Dengan HIV/AIDS (ODHA) maka infeksi TB laten tersebut dengan mudah berkembang menjadi TB aktif. Pada orang yang tidak terinfeksi HIV, bila terinfeksi kuman TB maka hanya sekitar 10\% yang akan menjadi sakit TB sepanjang hidupnya. Sedangkan pada orang dengan HIV positif akan berisiko 29 kali lebih besar untuk menderita TB aktif dengan mereka yang HIV negatif. Sekitar $60 \%$ infeksi TB laten akan berkembang menjadi TB aktif pada orang dengan sistem imunitas yang menurun. ${ }^{(11)}$

Hasil penelitian menunjukkan bahwa tidak ada hubungan yang bermakna antara kepatuhan minum obat dengan efek samping obat. Dari 6 responden yang patuh dalam minum obat mengalami efek samping pengobatan (100\%). Hasil analisis dengan uji chi square di peroleh nilai $P=1,000 \quad(\geq 0,05) \quad$ dengan menggunakan alpha $5 \% \quad(0,05)$ sehingga disimpulkan bahwa tidak ada hubungan antara kepatuhan minum ARV dengan efek samping obat. Seperti pada obat lainnya ARV memiliki berbagai efek samping. Dalam 
beberapa minggu pertama efek samping yang muncul pada gastrointestinal adalah mual, muntah dan diare. Efek samping hanya membutuhkan terapi simptomatik. Ruam dan toksisitas hati umumnya terjadi akibat obat NNRTI, namun dapat juga oleh obat NRTI seperti ABC dan PI. Apabila timbul efek samping maka harus segera ke pelayanan kesehatan yang memberikan obat tersebut untuk diatasi gejala efek samping yang muncul. Penghentian obat ARV sementara atau meneruskan pengobatan ARV akan dipertimbangkan oleh dokter yang memberikan terapi sesuai dengan gejala efek samping yang muncul. ${ }^{(12)}$

Analisis kepatuhan minum obat dengan status tumbuh kembang diketahui 7 responden yang tidak patuh dalam minum obat tidak mengalami gangguan tumbuh kembang (100\%). Hasil uji chi Square di peroleh nilai $\mathrm{P}$ value $1,000 \quad(\geq 0,05) \quad$ dengan menggunakan alpha $5 \%(0,05)$ dapat disimpulkan bahwa secara statistik tidak ada hubungan kepatuhan minum obat dengan status tumbuh kembang. Hal ini dimungkinkan karena stadium klinis pada pasien yang diteliti masih berada pada stadium awal. Adapun penyebab langsung adanya gangguan tumbuh kembang pada anak HIV karena virus HIV menyebabkan penurunan daya tahan tubuh sehingga memudahkan infeksi masuk ke dalam tubuh anak dan anak akan menjadi lebih sering sakit sehingga pertumbuhan dan perkembangannya terlambat dibandingkan dengan anak yang jarang mengalami sakit. ${ }^{(8)}$ Secara klinis kepatuhan minum ARV sangat penting untuk menekan replikasi virus, menormalkan imunitas, memulihkan hemostasis energi untuk tumbuh kembang pasien. Penelitian Herlina et al. (2016) menyatakan bahwa gangguan tumbuh kembang seperti gangguan kognitif akan terjadi lebih berat pada anak dengan stadium klinis yang berat. ${ }^{(13)}$

Hasil analisis menunjukkan bahwa ada hubungan yang bermakna antara kepatuhan minum obat dengan penyakit penyerta. Dari 3 responden yang tidak patuh dalam minum obat mengalami penyakit penyerta kandidiasis (42,9\%). Hasil uji Kendall's Tau di peroleh nilai $P=0,02(\leq 0,05)$ dengan menggunakan alpha $(0,05)$ yang berarti secara statistik ada hubungan antara kepatuhan minum ARV dengan penyakit penyerta yang timbul. Mengingat sistem imunitas anak belum matur dan anak dengan HIV sangat rentan terkena penyakit, sehingga anak mudah terkena penyakit 
yang berat dan berlangsung cepat proses penyakitnya. ${ }^{(14)}$

Penyakit rongga mulut masih merupakan salah satu manifestasi paling umum pada pasien anak HIVpositif, dan sering kali merupakan bentuk pertama di mana imunosupresi. $^{(14)}$ Salah satu penyakit mulut tersebut adalah kandidiasis yang merupakan penyakit penyerta yang umum terjadi pada anak dengan HIV. ${ }^{(13)}$ Selain kandidiasis penyakit penyerta lain yang sering timbul adalah diare, pneumonia, TB Paru. Apabila anak mengalami ketidak patuhan dalam minum obat maka CD4 akan menurun, daya tahan tubuh anak menurun sehingga penyakit atau virus mudah masuk ke dalam tubuh anak tersebut. ${ }^{(8)}$ Gejala dan infeksi oportunistik akan lebih berat apabila stadium klinisnya berat. $^{(13)}$

\section{Kesimpulan}

Hasil penelitian menunjukkan bahwa tidak ada hubungan antara kepatuhan minum obat dengan status tumbuh kembang dan efek samping obat tetapi ada hubungan antara kepatuhan minum ARV dengan penyakit penyerta selama pengobatan. Kepatuhan minum obat ARV sangat penting untuk untuk mempertahankan kesehatan anak. Kepatuhan terhadap terapi atau sejauh mana perilaku anak mengikuti anjuran pengobatan merupakan tantangan yang harus dihadapi bersama antara profesional kesehatan keluarga atau pengasuh dan anak yang menjalankan terapi ARV.

\section{Saran}

Perlu ada penelitian lebih lanjut tentang dampak dari kepatuhan pengobatan ARV secara kuantitatif dengan mix methods untuk mendapatkan informasi yang lebih mendalam dan untuk mengetahui faktor yang mempengaruhi kepatuhannya.

\section{Daftar Pustaka}

1. Direktorat Jendral P2P. Laporan perkembangan HIV AIDS dan PIMS Triwulan II Tahun 2019. In Jakarta: Kementrian Kesehatan Republik Indonesia; 2019.

2. Stevens $M$, Kirsh B, Nixon SA. a scoping review. 2014;36(10):86574.

3. Hornschuh S, Dietrich JJ, Tshabalala C, Laher F. Antiretroviral treatment Adherence: Knowledge and Experiences among Adolescents and Young Adults in Soweto, South Africa. AIDS Res Treat. 2017;1-8.

4. Kementrian Kesehatan RI. Program Pengendalian HIV AIDS dan PIMS di Fasilitas Kesehatan Tingkat Pertama: Petunjuk Teknis. 2016; 
5. Kim S-H, M.Gerver S, Fidler S, Ward H. Adherence to antiretroviral therapy in adolescents living with HIV: Systematic review and metaanalysis. Aids. 2014;28:1945-56.

6. Haryatiningsih A, Alam A, Deti T, Sitorus R. Hubungan lamanya terapi ARV dengan kepatuhan minum obat pada anak HIV di Klinik Teratai. 2016;3:80-3

7. Corrigan B, Mukui I, Mulenga. Characteristics of Treatmentexperienced HIV-infected African Children and adolescents initiating darunavir and/or etravirine-based Antiretroviral treatment. Pediatr Infect Dis J. 2018;37(7):669-72.

8. Ernawati E. Growth and development of children suffering from HIV/AIDS. Media Keperawatan Indones. 2018;1(1):27.

9. Handayani RS, Yuniar Y, Susyanty $A L$, Lestary $H$, Sugiharti $S$. Gambaran Peran Apoteker sebagai Konselor dalam Pengobatan HIVAIDS pada Ibu dan Anak. Media Penelit dan Pengemb Kesehat. 2018;

10. World Health Organization. The Use of Antiretroviral Drugs for Treating and Preventing HIV Infection (second). France; 2016.

11. Kemenkes. Pedoman Nasional Pengendalian Tuberkulosis 2014.
Pedoman Nasional Pengendalian Tuberkulosis. 2014.

12. Kementrian Kesehatan RI. Pedoman penerapan terapi hiv pada anak. In Jakarta: Kementrian Kesehatan RI; 2014. p. 1-96.

13. Herlina $H$, Kurniati N, Prawitasari $T$, Soedjatmiko S, Hadinegoro SR, Mangunatmadja I, et al. Gambaran fungsi kognitif HIV anak yang telah memperoleh terapi Antiretrovirus. Sari Pediatr. 2016;18(2):100.

14. Lauritano D, Moreo G, Oberti L, Lucchese A, Di Stasio D, Conese $\mathrm{M}$, et al. Oral manifestations in HIVpositive children: A systematic review. Pathogens. 2020;9(2):1-15. 